Research article

\title{
EVALUATION OF ZACKEL LAMB MEAT QUALITY WITH THE AIM OF INCREASING THE CONSERVATION VALUE OF THE BREED
}

\author{
SAVIĆ Mila ${ }^{*}$, BALTIĆ Milan², BECSKEI Zsolt ${ }^{1}$, DIMITRIJEVIĆ Blagoje ${ }^{3}$, \\ DIMITRIJEVIĆ Vladimir ${ }^{1}$, SAVIĆ Đorde ${ }^{4}$, VEGARA Mensur ${ }^{5}$
}

\begin{abstract}
${ }^{1}$ Department for Animal Breeding, Faculty of Veterinary Medicine, University of Belgrade, Serbia, ${ }^{2}$ Department for Food Hygiene and Technology, Faculty of Veterinary Medicine, University of Belgrade, Serbia, ${ }^{3}$ Clinic for ruminants and pigs, Faculty of Veterinary Medicine, University of Belgrade, Serbia, ${ }^{4}$ Department for Pediatric Surgery, Faculty of Medicine, University of Belgrade, Serbia, ${ }^{5}$ Department of International Environment and Development Studies, Norwegian University of Life Sciences NMBU, Ås, Norway
\end{abstract}

(Received 19 May; Accepted 20 November 2014)

The objective of the study was to perform and evaluate the advanced phenotypic characterization of endangered Zackel sheep types, especially their productive potential and meat quality traits. Meat quality characteristics ( $m$. longissimus dorsi) were evaluated in lambs of three types of autochthonous Zackel sheep: Sjenica sheep, Lipe sheep and Vlashko Vitoroga sheep, reared in traditional habitats in a sustainable management system. For the evaluation of sensory characteristics of lamb meat, quantitative descriptive analysis was performed according to ISO 6564:1985, i.e. structural intensity scale of seven points. All Zackel meat samples had an overall acceptability, the most favorable being in Sjenica sheep, with detected differences between Sjenica and Vlashko Vitoroga sheep $(p<0.01)$, as well as between Lipe and Vlashko Vitoroga sheep $(p<0.05)$. For the determination of fatty acids profile the prepared samples were analyzed using gas chromatography. The results showed that all tested lamb meat samples contain favorable amounts of conjugated linoleic acid (CLA). The average content of conjugated linoleic acid was higher in Sjenica lamb meat compared with Lipe lamb meat, and the difference was significant $(\mathrm{p}<0.01)$. It is also shown that examined samples of Sjenica, Lipe and Vlashko Vitoroga lambs, compared to many other exotic and local breeds, were characterized by preferable values of $n-6: n-3$ fatty acid ratio. Polyunsaturated fatty acid $n-6: n-3$ ratio difference between tested Zackel types was not significant. The favorable fatty acid profile, important for human health and especially for infant and children nutrition, raises the interest for sustainable production and conservation of Zackel sheep.

Key words: Zackel sheep, animal genetic resources, lamb meat, sensory characteristics, fatty acid composition

Corresponding author: e-mail: mij@beotel.net 


\section{INTRODUCTION}

The knowledge of the importance of animal genetic resources and the management of these resources are very important objectives of current livestock production. Official data clearly exhibit the presence of serious threats to sheep genetic resources on the global level and emphasize the need for appropriate conservation measures [13]. According to Global Databank for Animal Genetic Resources [4] sheep breeds risk status data show that a large number of breeds is extinct, some breeds have a critical status (61), while many breeds are presently endangered or are of unknown status [57]. Unfavorable influence of climate changes and occurrence of new diseases in sheep make the conservation of locally adapted sheep breeds highly important [8].

The most important autochthonous sheep breed in Serbia is Zackel sheep. This breed has developed under modest biogeographic conditions and exhibits a high degree of adaptation to environmental conditions, such as climate and specific phytocenotic conditions. Great phenotype diversity is identified within the Zackel sheep breed. Zackel sheep is a triple purpose, low production breed, included in intensive cross-breeding programs with Wurttemberg and Ile de France breed, the fact that additionally makes its adaptive potentials and genetic variability neglected and its pure breed survival threatened. Characterization and determination of the conservation value for certain Zackel types have been evaluated in previous researches [9-11].

According to FAO Guidelines for in vivo conservation of animal genetic resources, the breeding strategy must be based on the identification and application of sustainable breeding options for breeds under conservation, with special attention to advanced characterization of adaptive and productive breed traits [12]. Studies of adaptive fitness traits and genetic resistance to parasite infections of Zackel sheep types have been previously performed [13].

The objective of the study was to perform and evaluate the advanced phenotypic characterization of Zackel sheep types, especially their productive potential and meatquality traits. Special attention in this study is focused on Lipe sheep and Vlashka Vitoroga sheep, as endangered breeds (registered at the Endangered Maintained breeds list FAO DAD IS 2012), and the most important type, Sjenica sheep, which is not at risk, but is genetically diluted, due to cross breeding [4].

\section{MATERIAL AND METHODS}

\section{Animals}

The study was carried out on 24 lamb carcasses of both sexes, eight lambs per each of three types of autochthonous Zackel sheep. The lambs were slaughtered at 90-100 days of age, mean weight of $26.74 \pm 1.85 \mathrm{~kg}, 25.24 \pm 2.12 \mathrm{~kg}$ and $23.42 \pm 2.35 \mathrm{~kg}$ for Sjenica sheep, Lipe sheep and Vlashko Vitoroga sheep, respectively. All types of 
Zackel lambs were produced in an extensive, sustainable management system. Sjenica sheep is reared on the Sjenica-Pester plateau (900-1200 m altitude) in southwestern Serbia, the Lipa sheep in grassland fields in lower Morava valley in Northern Serbia and the Vlashko Vitoroga type in the lowland pastures in South Eastern Banat region. Feeding systems were based on grazing of native pastures.

\section{Sampling and panel}

All the lambs were slaughtered at a registered slaughter house; the study was done in full accordance with the Animal Welfare Act. Before slaughtering, according to a standard operative procedure, lambs were fasted for $12 \mathrm{~h}$. The lamb carcasses were refrigerated at $+4^{\circ} \mathrm{C}$ for $24 \mathrm{~h}$. The next day, muscle samples from cold carcasses were taken. Two slices of $m$. longissimus dorsi (at the first lumbar vertebra) were sampled for sensory and intramuscular fatty acid analysis. The samples were vacuum packed in plastic bags, stored at $+4^{\circ} \mathrm{C}$ and sent to the laboratory.

\section{Scoring of the sensory characteristics}

The selection and training of the evaluators were conducted in accordance with ISO 8586-2:2012 (Sensor Features - General guidance for the selection, training and monitoring of assessors; Part 2: Sensory assessors (experts). Quantitative descriptive analysis (evaluation of the acceptability-odor) was performed according to ISO 6564:1985, the structural intensity scale / eligibility of seven points, with the score of 7 being the maximum intensity / eligibility, and score of less than 3.5 marked the product as unacceptable. The odor intensity, flavor intensity, flavor quality and overall acceptability were scored. Color and odor of the meat samples were analyzed before thermal treatment. Before cooking the fat was removed from the $m$. longissimus dorsi. The samples of $m$. longissimus dorsi were grilled $\left(70^{\circ} \mathrm{C}\right.$ internal temperature) and cut into thin slices. Sensory analysis was done by an 8 member trained taste panel professional commission.

\section{Fatty acid composition}

For fatty acid composition of the $m$. longissimus dorsi samples stored as described above were used immediately after thawing. Subcutaneous fat was removed over the $m$. longissimus dorsi. Analysis was performed in accordance with ISO 5508 and ISO 5509 norms.

For the determination of fatty acids, total lipids were extracted by the method of rapid extraction with a solvent mixture of $\mathrm{n}$-hexane and iso-propanol $(60: 40 \mathrm{v} / \mathrm{v})$ on Dionex ASE 200 apparatus. The obtained extracts were evaporated under a stream of nitrogen (Dionex SE 500 apparatus), at $50^{\circ} \mathrm{C}$ until a dry lipid residue was obtained. The extracted lipid was used for the determination of fatty acids. 
Fatty acid methyl esters were prepared by trans-esterification with trimethylsulfonium hydroxide, according to the method EN ISO 5509:2007. Methyl esters were separated on a HP-88 column (column length $100 \mathrm{~m}$, inner diameter $0.25 \mathrm{~mm}$, film thickness 0.20 $\mu \mathrm{m}, \mathrm{J} \& \mathrm{~W}$ Scientific, USA) by capillary gas chromatography with a flame ionization detector (Shimadzu 2010, Kyoto, Japan). The injector temperature was $250^{\circ} \mathrm{C}$ and the detector temperature was set at $280^{\circ} \mathrm{C}$. The carrier gas was nitrogen with a flow rate of $1.33 \mathrm{ml} / \mathrm{min}$ and a split ratio of 1:50. The injected volume was $1 \mu \mathrm{l}$, and the total run time 50.5 min. Fatty acid methyl esters were identified based on retention time compared to the retention times of a mixture of fatty acid methyl esters present in the Supelco Component 37 FAME mix standard (Supelco, Bellefonte, USA).

\section{Statistical analysis}

Statistical treatment of the data was done by GraphPad Prism statistics 5.00 for Windows, GraphPad Software, San Diego California, USA. The tested parameters were presented by descriptive statistical method (mean value, standard deviation). One-way ANOVA with Tukey's multiple comparison test was performed to test the average value differences of sensory characteristics and fatty acid composition in lamb meat between three types of Zackel sheep.

\section{RESULTS}

Meat quality characteristics ( $m$. longissimus dorsi) were evaluated in lambs of three types of autochthonous Zackel sheep: Sjenica sheep, Lipe sheep and Vlashko Vitoroga sheep, reared in traditional habitats. The sensory characteristics of lamb meat of Sjenica sheep, Lipe sheep and Vlashko-Vitoroga sheep are presented in Table 1.

Table 1. Sensory characteristics of lamb meat of three Zackel sheep types

\begin{tabular}{lccc}
\hline Sensory characteristic & $\begin{array}{c}\text { Sjenica sheep } \\
\mathbf{M} \pm \text { SD }\end{array}$ & $\begin{array}{c}\text { Lipe sheep } \\
\mathbf{M} \pm \text { SD }\end{array}$ & $\begin{array}{c}\text { Vlashko Vitoroga sheep } \\
\text { M } \pm \text { SD }\end{array}$ \\
\hline Colour & $6.19 \pm 0.35$ & $5.50 \pm 0.26$ & $5.19 \pm 0.25$ \\
Odour & $5.93 \pm 0,32$ & $5.25 \pm 0.27$ & $6.18 \pm 0.37$ \\
Juiciness & $6.06 \pm 0.32$ & $5.81 \pm 0.37$ & $5.56 \pm 0.32$ \\
Tenderness & $6.18 \pm 0.26$ & $6.12 \pm 0.23$ & $5.31 \pm 0.25$ \\
Odour and flavour (Aroma) & $6.12 \pm 0.23$ & $5.87 \pm 0.35$ & $5.81 \pm 0.37$ \\
Overall acceptability & $6.12 \pm 0.25 \mathrm{C}$ & $6.00 \pm 0.25 \mathrm{c}$ & $5.62 \pm 0.37$ \\
\hline
\end{tabular}

C, $\mathrm{c}-$ differences compared to Vlashko sheep.

Capital letters indicate significant difference $(p<0.01)$ between tested Zackel sheep types.

Small letters indicate significant difference $(\mathrm{p}<0.05)$ between tested Zackel sheep types.

The tested meat samples had a fine structure on cross section. Using quantitative descriptive analysis for sensory evaluation, it was determined that Sjenica lamb meat 
had the highest tenderness, juiciness, meat aroma and overall acceptability. All Zackel meat samples had preferable overall acceptability, the most favorable was in Sjenica sheep, with detected differences between Sjenica and Vlashko Vitoroga sheep (6.12 \pm 0.25 and $5.62 \pm 0.37$ respectively, $\mathrm{p}<0.01)$, Lipe and Vlashko Vitoroga sheep $(6.00 \pm$ 0.25 and $5.62 \pm 0.37$ respectively, $\mathrm{p}<0.05)$, but no statistical difference between Sjenica and Lipe sheep was detected (Table 1).

The established results are in accordance with a number of studies. They have confirmed that the interaction between breed and nutritional regimens with specific grass composition of pastures in the traditional habitat, has a big impact on odor and flavor of lamb meat. Consumers of this region prefer the flavor of pasture - fed lamb meat.

One of the most important research goals was to analyze CLA content in Zackel lamb meat, considering it's protective effects on some diseases, such as cancer, cardiovascular diseases, diabetes and immunomodulation. The results showed that all tested meat samples contain favorable amounts of conjugated linoleic acid (CLA). The average content of conjugated linoleic acid was higher in Sjenica lamb meat (4.49 \pm 0.59) compared with Lipe lamb meat $(3.59 \pm 0.22)$, and the difference was significant $(\mathrm{p}<0.01)$. Also, the difference between Vlashko Vitoroga $(4.24 \pm 0.17)$ and Lipe sheep $(3.59 \pm 0.22)$ was significant $(\mathrm{p}<0.01)$.

Table 2. Fatty acid content of lamb meat of three Zackel sheep types

\begin{tabular}{lccc}
\hline Fatty acids & $\begin{array}{c}\text { Sienica sheep } \\
\text { M } \pm \text { SD }\end{array}$ & $\begin{array}{c}\text { Lipe sheep } \\
\mathbf{M} \pm \text { SD }\end{array}$ & $\begin{array}{c}\text { Vlashko Vitoroga sheep } \\
\text { M } \pm \text { SD }\end{array}$ \\
\hline C14:0 & $2.323 \pm 0.23$ & $3.88 \pm 0.70$ & $2.31 \pm 0.22$ \\
C15:0 & $0.40 \pm 0.07$ & $0.44 \pm 0.05$ & $0.40 \pm 0.07$ \\
C16:0 & $23.57 \pm 2.43$ & $24.36 \pm 1.92$ & $25.14 \pm 1.04$ \\
C16:1 & $1.45 \pm 0.25$ & $1.71 \pm 0.21$ & $1.50 \pm 0.14$ \\
C17:0 & $1.29 \pm 0.24$ & $1.28 \pm 0.18$ & $1.17 \pm 0.13$ \\
C18:0 & $29.12 \pm 3.49$ & $23.15 \pm 3.24$ & $25.50 \pm 1.92$ \\
C18:1 cis9 & $33.79 \pm 2.53$ & $37.80 \pm 4.17$ & $35.84 \pm 3.74$ \\
C18:2 n-6 & $2.36 \pm 0.25$ & $2.63 \pm 0.33$ & $2.41 \pm 0.16$ \\
C18:3 n-3 & $1.16 \pm 0.26$ & $1.10 \pm 0.03$ & $1.08 \pm 0.05$ \\
C20:0 & $0.23 \pm 0.01$ & $0.22 \pm 0.01$ & $0.22 \pm 0.01$ \\
C20:3 n-6 & $0.02 \pm 0.00$ & $0.04 \pm 0.01$ & $0.03 \pm 0.01$ \\
C20:5 n-3 & $0.02 \pm 0.00$ & $0.01 \pm 0.01$ & $0.03 \pm 0.01$ \\
C22:1 + C20:4 & $0.11 \pm 0.02$ & $0.08 \pm 0.02$ & $0.13 \pm 0.02$ \\
22:5 n-3 & $0.16 \pm 0.06$ & $0.15 \pm 0.03$ & $0.16 \pm 0.06$ \\
\hline
\end{tabular}

It is also shown that the examined samples of Sjenica, Lipe and Vlashko Vitoroga lambs, compared to many other exotic and local breeds, were characterized by 
preferable values of n-6:n-3 ratio, important for human health. Polyunsaturated fatty acid $n-6: n-3$ ratio between tested Zackel types was not significant. The results showed an evolutionary adaptation of different Zackel types reared on a specific grazing system in a traditional habitat, which gives advantage to the balance of meat fatty acid composition (Table 3).

Table 3. Saturated, monounsaturated, polyunsaturated, CLA, omega- 6 and omega-3 fatty acid content in lamb meat of three Zackel sheep types

\begin{tabular}{lccc}
\hline Fatty acids & $\begin{array}{c}\text { Sjenica sheep } \\
\text { M } \pm \text { SD }\end{array}$ & $\begin{array}{c}\text { Lipe sheep } \\
\text { M } \pm \text { SD }\end{array}$ & $\begin{array}{c}\text { Vlashko Vitoroga } \\
\text { sheep } \\
\text { M } \pm \text { SD }\end{array}$ \\
\hline I SFA (Saturated fatty acids) & $56.38 \pm 2.91^{\mathrm{b}}$ & $48.73 \pm 7.21$ & $54.38 \pm 2.91$ \\
$\Sigma$ MUFA (Monounsaturated fatty acids) & $34.42 \pm 2.75$ & $39.58 \pm 2.60^{\mathrm{A}}$ & $36.99 \pm 2.30$ \\
$\Sigma$ PUFA (Polyunsaturated fatty accids) & $3.74 \pm 0.57^{\mathrm{b}}$ & $2.93 \pm 0.35^{\mathrm{b}}$ & $3.53 \pm 0.57$ \\
CLA & $4.49 \pm 0.59^{\mathrm{B}}$ & $3.59 \pm 0.22$ & $4.24 \pm 0.17^{\mathrm{b}}$ \\
$\Sigma \mathrm{n}-3$ & $1.34 \pm 0.44$ & $1.26 \pm 0.05$ & $1.27 \pm 0.44$ \\
$\Sigma \mathrm{n}-6$ & $2.38 \pm 0.20$ & $2.67 \pm 0.34^{\mathrm{C}}$ & $2.24 \pm 0.17$ \\
$\mathrm{n}-6 / \mathrm{n}-3$ & $1.77 \pm 0.45$ & $2.12 \pm 0.21$ & $1.92 \pm 0.44$ \\
\hline
\end{tabular}

A, a - differences compared to Sjenica sheep; B, b - differences compared to Lipe sheep;

$\mathrm{C}, \mathrm{c}$ - differences compared to Vlashko sheep.

Capital letters indicate significant difference $(p<0.01)$ between tested Zackel sheep types.

Small letters indicate significant difference $(\mathrm{p}<0.05)$ between tested Zackel sheep types.

\section{DISCUSSION}

Recognizing that locally adapted animal breeds gained genetic resistance and adaptability through the evolutionary process, breeding strategies in sustainable farming practices today are far more attuned to the preservation and utilization of autochthonous breeds [13]. Investigations of specific characteristics of autochthonous sheep breeds, especially advanced characterization of the productive potentials and specific product characteristics are important topics for a sustainable conservation strategy $[11,14]$.

In the recent years there is a growing interest for the consumption of animal products with a favorable content of fatty acids with a positive effect on human health. Remarkable attention has been laid on the relative proportion of n-6 and n-3 fatty acids, which can be a preventive factor for cardiovascular diseases, certain malignant and autoimmune disease, such as lupus, rheumatoid arthritis, etc $[15,16]$. The interest in investigating lamb meat characteristics has been increasing, considering that lamb meat used in the weaning diet of children is presumed to have a lower allergenicity than other forms of red meat. Lamb meat consumption in children with atopic dermatitis and multiple food hypersensitivity has resulted in significant clinical improvements. Lamb meat has a special importance in infant nutrition, because it provides a unique 
fatty acid profile what is thought to be optimal for neonatal growth and development $[17,18]$.

Fatty acid composition and sensory characteristics of lamb meat are identified in numerous international and local sheep breeds, such as Podhale Zackel and Coloured mountain sheep; Zackel and Bluefaced Leicester; Aragonesa, Merino, Welsh Mountain breed and Chilote; local Romanian breeds, like Carabash, Tsigai and Tsurcana; also Zackel cross-types [19-22]. These analyzes have shown that many factors in the production, such are diet, age of weaning, breed, sex and body weight, have effects on muscle fatty acid composition and sensory characteristics of lamb meat $[15,23]$. The interaction between a breed and environmental conditions could play an important role in the variability of fatty acid composition and sensory characteristics of lamb meat $[21,23,24]$. Within the aim of biodiversity conservation, these facts emphasize the importance of collecting environmental data relevant for production characteristics and provide a comprehensive description of traditional habitat, such as specific botanical biodiversity in which animals are reared [14, 24-27].

The results of our investigations are in accordance with a number of studies, and have proved that traditional habitat conditions have an influence on muscle fatty acid composition and flavor of lamb meat. The most favorable fatty acid profile and sensory characteristics were obtained in Sjenica sheep, followed by Lipe sheep and Vlashko Vitoroga sheep. The favorable fatty acid profile, important for human health and especially for infant and children nutrition, raises the interest for sustainable production of Zackel sheep. Our results of lamb meat favorable content of CLA and of n-6:n-3 ratio, contribute to the advanced phenotypic characterization of Zackel sheep types, the determination of locally adapted breeds value and in making a realistic decision for the promotion of sustainable use of Zackel breed.

\section{Acknowledgement}

This study was supported the Ministry of Education and Science of Republic of

Serbia, Grant No. TR 31085 and The Norwegian Programme in Higher Education, Research and Development in the Western Balkans 2010-2014. HERD/Agriculture Project 09/1548, 332160 UA.

\section{REFERENCES}

1. FAO: Preparation of national strategies and action plans for animal genetic resources. FAO Animal Production and Health Guidelines No.2. 2009.

2. FAO: Breeding strategies for sustainable management of animal genetic resources. FAO Animal Production and Health Guidelines No.3. 2010.

3. FAO: In vivo conservation of animal genetic resources. FAO animal production and health guidelines No.14. 2013a.

4. FAO DAD IS: Domestic Animal Diversity Information System (FAO). 2012.

5. FAO: Phenotypic characterization of animal genetic resources, Animal Production and Health Guidelines No.11. 2012a. 
6. FAO: Status and trends of animal genetic resources - 2012. Intergovernmental Technical Working Group on Animal Genetic Resources for Food and Agriculture. 2012b.

7. FAO: Report of a consultation on the definition of breed category. Intergover mental technical working group on animal genetic resources for food and agriculture. Item 5 of the Provisional Agenda. 2012c.

8. Hoffmann I: Climate change and the characterization, breeding and conservation of animal genetic resources. Anim Genet 2010, 41: 32-46.

9. Trailović R, Djedović R, Bogdanović V, Jovanović S, Ćinkulov M: Pramenka Breed Types of Serbia. In: Porcu K and Marković B (eds): Catalogue of West Balkan Pramenka Sheep Breed Types. Faculty of Agricultural Sciences and Food, Skopje, 2006, 74-88.

10. Ćinkulov M, Popovski Z, Porcu K, Tanaskovska B, Hodžić A, Bytyqi H, Mehmeti H, Margeta V, Djedović R, Hoda A, Trailović R, et al.: Genetic diversity and structure of the West Balkan Pramenka sheep types as revealed by microsatellite and mitochondrial DNA analyses. J Anim Breed Genet 2008, 125: 417-426.

11. Savić M, Trailović R, Petrujkić B, Bečkei Ž, Dimitrijević V, Dimitrijević B: Determining the value of Vlashko Vitoroga Zackel sheep for conservation process., Acta Vet-Beograd 2013, 63: 621-631.

12. FAO: Draft guidelines on in vivo conservation of animal commission on genetic resources for food and agriculture. Item 4.2 of the Provisional Agenda Fourteenth Regular Session. 2013b.

13. Dimitrijević B, Borozan S, Jović S, Bacić D, Katić Radivojević S, Stojanović S, Savić M: The effect of the intensity of parasitic infection with Strongyloides papillosus and albendazole therapy on biochemical parametars in sheep blood. Acta Vet-Beograd 2013, 63: 581-601.

14. Popović-Vranješ A, Savić M, Pejanović R, Jovanović S, Krajinović G: The effect of organic milk production on certain milk quality parameters. Acta Vet-Beograd 2011, 61: 415-421.

15. Schmid A, Collomb M, Sieber R, Bee G: Conjugated linoleic acid in meat and meat products. Meat Sci 2006, 73: 29-41.

16. Terré M, Nudda A, Boe F, Gaias G, Bach A: Performance, immune response and fatty acid profile in lambs supplemented with a CLA-mixture. J Anim Feed Sci Techn 2011, 165: 1-7.

17. Enser M, Hallett KG, Hewett B, Fursey GA, Wood JD, Harrington G: Fatty acid content and composition of UK beef and lamb muscle in relation to production system and implications for human nutrition. Meat Sci 1998, 49: 329-341.

18. Nudda A, McGuire MK, Battacone G, Manca MG, Boe R, Pulina G: Documentation of fatty acid profiles in lamb meat and lamb-based infant foods. J Food Sci 2011, 76: H43-47.

19. Kawęcka A, Krupiński J: Sheep in the Polish carpathians: Genetic resources conservation of the podhale Zackel and coloured mountain sheep. Geomat Landmanag Landsc 2014, 1: $35-45$.

20. Gavojdian D, Cziszter L, Sossidou E, Pacala N: Improving performance of Zackel sheep through cross-breeding with prolific Bluefaced Leicester under semi-intensive and extensive production systems. J Appl Anim Res 2013, 41: 432-441.

21. Ramírez-Retamal J, Molares R, Martinez E, de la Barra R: Effect of the type of pasture on the meat characteristics of Chilote lambs. Food Nutrit Sci 2014, 5: 635-644.

22. Ghita E, Lazar C, Pelmus R, Voicu I: Comparative research on the aptitudes for meat production of the fattening lambs of local Romanian breeds. Biotechnology in Animal Husbandry 2010, 26: 13-20. 
23. Radzik-Rant A, Rant W, Rozbicka-Wieczorek A, Kuźnicka E: The fatty acid composition of longissimus lumborum muscle of suckling and early weaned dual-purpose wool/meat lambs. Archiv Tierzucht 2012, 3: 285-293.

24. Demirel G, Ozpinar H, Nazil B, Keser O: Fatty acids of lamb meat from two breeds fed different forage: concentrate ratio. Meat Sci 2006, 72: 229-235.

25. Scerra M, Luciano G, Caparra P, Foti F, Cilione C, Giorgi A, Scerra V: Influence of stall finishing duration of Italian merino lambs raised on pasture on intramuscular fatty acid composition. Meat Sci 2011, 89: 238- 242.

26. Grdović S, Savić M, Jovanović S, Popović-Vraneš, Petrujkić B, Bosančić D: The Analysis of Forage Quality for Organic Milk Production in Fruška Gora Region. Acta Vet-Beograd 2010, 60: 425-433.

27. Grdović S, Savić M, Bečkei Ž, Dimitrijević B: Biodiversity and traditional sheep grazing in the South Banat region. Acta Vet-Beograd 2012, 62: 709-716.

\title{
ISPITIVANJE KVALITETA MESA JAGNJADI PRAMENKE U CILJU POVEĆANJA VREDNOSTI RASE U PROCESU KONZERVACIJE
}

\author{
SAVIĆ Mila, BALTIĆ Milan, BECSKEI Zsolt, DIMITRIJEVIĆ Blagoje, \\ DIMITRIJEVIĆ Vladimir, SAVIĆ Đorde, VEGARA Mensur
}

Predmet istraživanja je bio da se bliže ispitaju fenotipske osobine različitih ugroženih sojeva pramenke, a naročito potencijal za proizvodnju i kvalitet mesa. Karakteristike kvaliteta mesa ( $m$. longissimus dorsi) su ispitivane kod tri soja autohtone rase pramenke, i to kod sjeničkog, lipskog i vlaško vitorogog soja, koji se gaje u tradicionalnim uslovima. Za kvantitativnu deskriptivnu analizu senzornih osobina mesa jagnjadi korišćene su strukturne skale intenziteta sa sedam tačaka (ISO 6564:1985). Svi uzorci mesa pramenke su imali visoku ocenu ukupne prihvatljivosti, najpovoljnije je ocenjen sjenički soj, uz utvrđenu razliku između sjeničkog i vlaško vitorogog soja $(p<0,01)$, kao $\mathrm{i}$ između lipskog $\mathrm{i}$ vlaško vitorogog soja $(\mathrm{p}<0,05)$. Za određivanje sadržaja masnih kiselina uzorci su analizirani korišćenjem gasne hromatografije. Rezultati su pokazali da svi ispitivani sojevi pramenke sadrže povoljan masnokiselinski sastav uz visok sadržaj konjugovane linoleinske kiseline (CLA). Utvrđen je veći prosečan sadržaj konjugovane linoleinske kiseline kod sjeničkog soja u odnosu na lipski soj $(\mathrm{p}<0,01)$. Takođe je utvrđeno da ispitivani uzorci sjeničkog, lipskog i vlaško vitorogog soja, poređeni sa drugim egzotičnim i lokalnim rasama, imaju bolji odnos n-6:n-3 polinezasićenih masnih kiselina, a statistička značajnost razlike između pojedinih sojeva pramenke nije utvrđena. Poželjan profil masnih kiselina, značajan za zdravlje ljudi, a posebno za ishranu odojčadi i dece, podstiče interes za održivu proizvodnju i proces očuvanja ugroženih sojeva pramenke. 